\title{
The Implementation of Integrated Patient Progress Notes in Interprofessional Collaborative Practice
}

\author{
Puput Risti Kusumaningrum ${ }^{1}$, Edi Dharmana², Madya Sulisno ${ }^{3}$
}

\author{
'STIKes Muhammadiyah Klaten, Mahasiswa Magister Keperawatan FK UNDIP \\ ${ }^{2}$ Fakultas Kedokteran Universitas Diponegoro Semarang. \\ ${ }^{3}$ Departemen IImu Keperawatan, Fakultas Kedokteran, UNDIP, Semarang. \\ E-mail: puput.risti_ners@yahoo.co.id
}

\begin{abstract}
Abstrak
Interprofessional Collaborative Practice (IPCP) adalah bentuk kolaborasi dan komunikasi di antara profesi kesehatan dalam pendekatan terkoordinasi untuk berbagai pengambilan keputusan tentang masalah kesehatan untuk memastikan bahwa perawatan yang diberikan dapat diandalkan dan berkelanjutan. Implementasi IPCP membutuhkan media pendukung, yaitu, dengan mengintegrasikan catatan perkembangan pasien ke dalam yang terintegrasi. Oleh karena itu, petugas kesehatan dapat berkolaborasi dengan menggunakan catatan perkembangan pasien terintegrasi ini. Penelitian ini bertujuan untuk mengeksplorasi dokumentasi implementasi catatan perkembangan pasien terintegrasi di IPCP oleh dokter, perawat, apoteker, ahli gizi, dan fisioterapis di ruang rawat inap Rumah Sakit UGM, Yogyakarta. Penelitian ini menggunakan desain kualitatif dengan pendekatan fenomenologis hermeneutik. Sampel direkrut menggunakan purposive sampling, yang melibatkan 14 peserta utama. Data dikumpulkan melalui wawancara mendalam dengan wawancara semi terstruktur dan dianalisis menggunakan teknik analisis isi. Hasil mengidentifikasi 4 tema terkait, termasuk: (1) pemahaman, (2) kepatuhan, (3) media penggerak IPCP, (4) beban kerja, sikap, perilaku dan kebijakan (sosialisasi) yang menghambat implementasi IPCP. Studi ini menyimpulkan bahwa mendokumentasikan catatan perkembangan pasien terintegrasi dapat mendorong praktik kolaboratif untuk mengoptimalkan layanan terintegrasi.
\end{abstract}

Kata Kunci: Catatan Perkembangan Pasien, Praktik Kolaboratif Interprofesional, IImu Multidisiplin

Interprofessional Collaborative Practice (IPCP) is a form of collaboration and communication among the health professions in a coordinated approach to various decision-making on health issues to ensure that the care provided is reliable and sustainable. The implementation of IPCP requires supporting media, i.e., by integrating the patient progress notes into the integrated one. Therefore, the health workers can collaborate by the use of this integrated patient progress note. This study aimed to explore the documentation implementation of integrated patient progress notes in IPCP by doctors, nurses, pharmacists, nutritionists, and physiotherapists in the inpatient wards of UGM Hospital, Yogyakarta. This study used a qualitative design with a hermeneutic phenomenological approach. The samples were recruited using purposive sampling, involving 14 main participants. The data were collected through in-depth interviews with semistructured interviews and analyzed using the content analysis technique. The results identified 4 related themes, including: (1) the understanding, (2) the compliance, (3) the driving media of IPCP, (4) the workloads, attitudes, behaviors and policies (socialization) which inhibited the implementation of IPCP. 
This study concluded that documenting the integrated patient development record could foster collaborative practices to optimize the integrated services.

Keywords: Patient Development Record, Interprofessional Collaborative Practice, Multidisciplinary Science

Article info:

Article submitted on July 04, 2017

Articles revised on August 06, 2017

Articles received on September 26, 2017

DOI: http://dx.doi.org/10.21927/jnki.2018.6(1).32-41

\section{INTRODUCTION}

Interprofessional Collaborative Practice (IPCP) is a form of collaboration and communication among the health professions in a coordinated approach to various decisionmaking on health issues to ensure that the care provided is reliable and sustainable (1)(2).

IPCP is very important in making collective decisions and improving effectiveness and efficiency in the delivery of service to patients. In this matter, each health profession involved should have a sense of trust, totality, tolerance, fairness, and togethernessso that the service provided can be optimal (3). This is in line with Doughertyet al. (2005) who argued that collaboration could decrease mortality risk and increased patient satisfaction (4).

Barriers in interprofessional collaboration can be a major cause of medical errors, nursing errors or adverse events (5). The Institute of Medicine (2000) reported the patient mortality rate in hospitals reached to 44,000 to 98,000 patients each year. In 2010, The Center for Medicare and Medicaid reported $13.5 \%$ of patients experienced adverse events, and the costs they had to spend to resolve the problems reached $\$ 4.4$ billion (US Department of Health and Human Services, 2010). In 2011, the Joint Commission Sentinel Event Statistic received 1,243 reports; $60 \%$ of them were due to problems in collaboration (6).

IPCP has not yet been optimally implemented so far. One of the issues emerging is because many health professions still use a type of medical recordwhich is separated with care records and other health profession records used to document the condition of the patient (7)(8). The written records do not describe detail information about the patient's responses and what the patient feels. Even, some health professionals may not read the record since it is writtenon separate sheets (7)(9)(10).

The 2012 hospital accreditation guideline states caregiver professionals should implement an integrated patient care, which includes a dynamic care process and involvement of many healthcare practitioners such as nurses, doctors, midwives, nutritionists, pharmacists, therapists, and many others. This integrated care may also involve otherwork units and services described in the care record (11). Dealing with this issue, it is essential to optimize the implementation of IPCP among the health professions. Therefore, the care record can be written more optimally since all health professions write in the same sheet, and thus minimize miscommunication, reduce the number of adverse events, and in the end, it can improve patient safety and give impacts on improving the quality of services (12)(13).

\section{MATERIALS AND METHODS}

This study used a qualitative design with a phenomenological approach. The population included medical specialists, nurses, pharmacists, nutritionists and physiotherapists in UGM Hospital 
Yogyakarta.The samples were recruited using a nonprobability sampling with purposive sampling technique (14)(15). Fourteen participants were recruited based on the inclusion criteria, which included (1) having work experience of $\geq 1$ year, (2) obtaining a degree of education of either medical specialist, nurse (at least DIII), pharmacist (pharmacist profession), nutritionist (bachelor), and physiotherapist (at least DIII), and (3) expressing a voluntary participation as evidenced by signing an informed consent prior to the study. Meanwhile, the exclusion criteria were the health professions who were on leave, refused to participate, or could not continue the interviews due to illness, and expressed refusal to have next interview sessions.

The data were analyzed using a content analysis technique, which included transcribing the interviews, determining meaning units to search for relationships between words, sentences or paragraphs, and performing data abstractions to form several themes.

\section{RESULTS AND DISCUSSION}

The participants involved in this study were 14 , consisting of three medical specialists, three nurses, twopharmacists, three nutritionists, and three physiotherapists. This study revealed four themes, describing the implementation of integrated patient progress notes (IPPN) in the implementation of IPCP. The followings are the resulted themes.

Adequate understanding of the caregiver professional is importantin the implementation of integrated patient progress note (IPPN) documentation in IPCP by the role of each health profession

\section{Understanding of IPPN}

The participants revealed thatintegrated patient progress note is such a form of communication among the health professions which is written on the similar sheet and provides information on the progress of the patient until the patient discharge from the hospital. It is then not necessary for the health workers to go through different forms used for the patient monitoring. As a result, the health professional can manage the patient comprehensively to provide patientcentered care.A total of 10 health professions stated this accordingly, as follow:

"...it is information about the progress of the patient which is writtenon the same sheet" (P01)

"...there is no need to flip back the paper because the information is completed." (P04)

"... it is a note or evidence that we (health professional) monitorthe patient on a day-to-day basis." (P05) "...the note is written on the same sheet for all health professions that are patient-oriented." (P06)

"... it is more completed, and provides integrated patient progress note; more comprehensive." (P07)

"...it is an integrated record in which the health professions are patientcentered." (P14).

\section{The Caregiver Professionals}

All participants indicated that all medical or paramedical professions taking care of or handling the patients write and read the IPPN.

"...all professions can write and read on the same sheet, i.e., IPPN." (P02) "...thereis medical or paramedical personnel." (P05)

"... all health professions taking care of the patient write on the same sheet." (P08)

"... it is written by all health professions on the same sheet." (P13).

\section{The Implementation}

In implementing the documentation of integrated patient progress notes, all health 
professions work together, discuss and coordinate each other in decision making; all health professions also have an equal position. The following statements were presented by the participants:

"In writing the note, we coordinate each other in making the decisions. We also discuss it with each other." (P05)

"In the implementation, we have discussions with all teams involved, and we workcollaboratively." (P07)

"The patient management can be performed more quickly since all health personnel cooperates with each other." (P09).

\section{The Role of the Health Professions}

The participants stated that the fulfillment of IPPN requires the roles of each health profession according to their respective disciplines so that collaborative practices can be created, and thus will accelerate healing and reduce the adverse events. The following statements were presented by the participants.

"... the doctor in charge of patient mainly functions to coordinate the patient problems; the others give some inputs." (P10)

"...the doctor in charge of thepatient will establish themedical diagnosis, give the therapy, and make adecisionregarding the treatment given to the patient as well as make a decision on the patient's discharge from thehospital." (P09).

"The nurses have a role as acommunicatorbetween health professions, and between patients and health professions." (P07)

"My role as a physiotherapist is to educate patients to develop their selfreliance."(P03)

"I think the role of a nutritionist is to performnutritional care to patients, provide food, and give nutrition education." (P11)
"The role of a nutritionist includes nutritional assessment, nutritional calculations, and provide adiet to the patient." (P02)

"The physiotherapist works in the scope of the motion problem and body function." (P04)

The understanding of the health profession about IPPN documentation in the implementation of IPCP, in general,is suitable with the concept that IPPN is information about the development of patient care which is written in the same sheet by multiple disciplines. Therefore, it provides an ease for the caregivers to access information on patient progress. This integration requires each profession to perform their duties and authority professionally (11).

In implementing IPPN, the health professionals need to cooperate, discuss, and coordinate each other in making decisions. All health professions have anequal position so that the principle of collaboration can be created. This is in line witha study by Yani Lestariet al (2017) which indicated that interprofessional collaboration was well implemented in the writing of IPPN. The study indicated a strong and positive correlation in the aspect of cooperation, partnership, and decision making. Thus, better implementation of IPCP will result in better IPPN.

The health professions playing their respective fields of science willadvanceIPCP among the health professions, where the focus is on the patient or patient-centered care, sustainable and integrated in accordance with the concept of integrated care.

Patient-centered care requires integrated documentation that demands each profession to make a record of the patientin the same document. This method is expected to optimize IPCP among health professions. Furthermore, the fulfillment of the record can be more optimal since all health professions write on the same 
document. This will minimize miscommunication, lower the rate of adverse events, and in the end, improve patient safety and the quality of service (13)(16).

Compliance with the Integrated Patient Progress Note Implementation Requires Availability of Infrastructure and Facilities, Motivation, Evaluation and Feedback Monitoring System and Role of Case Manager.

\section{Level of Compliance}

Participants revealed that the fulfillment of patient progress note was integrated with SOAP format for medical specialists, nurses, pharmacists. Meanwhile, the physiotherapists documented the progress note with ADIME (nutritionist). They all write the date, time, signature and name. They write what they do and do what they have written. If the note is incorrectly written, they would cross it and put their initials. They also use standard abbreviations in their writing. The followings are some statements presented by the participants.

"Once I am done with the patient intervention, I immediately write it on the IPPN using ADIME format." (P01)

"After finishing a procedure to the patient, I then write it on the IPPN by writing the date, hour, and profession. Next to it, there is a column to writeaSOAP. I just put my signature and name there." (P03)

"If there is incorrect writing, I should cross it and put an initial. I should not erase it." (P05)

"If you write the abbreviated word, you should use the standard abbreviation...." (P08).

\section{Facilities and Infrastructures}

Participants mentioned that the facilities and infrastructures are readily available as stated by some participants below:
"Yes, we are all well facilitated. There are IPPN forms which are always available in accordance withthe hospital accreditation procedure. There are also pens in the nurse station for each of us, so we don't need to share the pen with others." (P03)

"The hospital has provided the facilities well. There are NIC/NOC books in the ward, so if we forget things, we can open the book. There is also a HER, even though it is not yet optimal in the inpatient ward. The IPPN sheets are also always available." (P05)

"Such facilities available are the IPPN sheets. They are easily accessible and never run out of the stock." (P07).

\section{Motivation (Reward and Punishment)}

Results of interviews revealed that forms of motivation (reward\&punishment) were manifested in compliments and warnings. The rewards in the form of money or punishment in the form of apay cuthave not been implemented, as stated by some participants below:

"Rewards in the form of money are not yet implemented." (P01)

"It is the commitment from us. Therefore, though there are no rewards and punishment, the program can run well." (P03)

"... The reward is not in the form of money. It is like when you are doing good, you will be given compliments. On the other hand, when you are doing something wrong, you will be given a warning." (P08)

"The money reward is not yet available. The punishment in the form of money cut is not available either." (P13) .

\section{Monitoring, Evaluation and Feedback System}

Participants stated that the monitoring, evaluation and feedback system had been implemented such as through CMRR (Close Medical Record Review). Some participants stated the following: 
"I have attended the CMRR. It is such an activity where one representative of each health profession is to do an evaluation, including the IPPN." (P01)

"...through the medical record review, we canevaluate the completeness of IPPN." (P02)

"To my knowledge, usually there is an integrated medical records audit including IPPN especially in the face of accreditation." (P07).

\section{The Role of Case Manager}

Participants revealed that the roles of acase managerare as facilitator, collaborator, performing monitoring and evaluation, as well as providing feedback. There were three case managers at the study site who carried out the task in accordance withtheir roles.

"There is already a case manager, who performs the evaluation and also supervision to the ward." (P02)

"There is a case manager. $\mathrm{He}$ is the one who checks whether there is a professional who is not yet visiting. He also does the supervision and gives a reminder." (P04)

"Here, there is also a case managerwho acts as a collaborator between health workers, and between patients and health workers." (P09)

The compliance of the health profession in documenting the IPPN in the implementation of IPCP requires facilities and infrastructure, monitoring system, evaluation and feedback, motivation and role of case manager. This study also shows that the procedure of writing IPPN documentation has been appropriately carried out. An understanding of IPPN writing by medical specialists, nurses, pharmacists and physiotherapists using SOAP and nutritionists using ADIME indicates that this understanding is important so that the patient planning can be clearer and more directional, more communicative and more collaborative; the interventions are clear and thus minimizeoverlapping events (17). This is congruent with a study by Patriciaet al. (2014) which found that integrated medical record makes the services more integrated, the patients are givenmore attention, andthe collaboration can be better (18).

The documentation of IPPN can be optimally implemented if there are adequate supporting facilities. The availability of such facilities and infrastructure as the documentation form/sheet, room for filling the IPPN, NIC/NOC books, pens for nurses in the wards are very important to motivate health professionsto carry out documentation according to the hospital standard (19).

Motivation related to reward and punishment in documenting IPPN in this study has not been structured and not yet applied. The fundamental principle of motivation is the power that drives the individual to do something to meet the need at a particular time (20). This is related to the need for such a system for IPPN documentation so that the compliance can be increased and the program runs optimally. Improving IPPN documentation can be done through monitoring and evaluation since regular and periodic monitoringand evaluation can result in some feedbacks submitted to the health profession for optimal improvement. Once the compliance behavior is developed, there will emerge positive cultureson the basis of awareness of the health professions that IPPN documentation is important to do in accordance with the standard (21).

The roleof case managers is very essential in developing positive cultures. One of the roles of case managers in implementing IPPN documentation is to monitor the filling of the records by the health professions of doctors, nurses, pharmacists, nutritionists, and physiotherapists. According to KARS (2015), a case manager is a hospital professional who conducts the patient service management, coordinates with the 
health professions and patient-family to meet the needs of patients and their families through communications and available resourcesto deliver quality outcomes. Some roles that a case manager should play includes the function of assessment, utility, planning, facilities, and advocacy, service coordination, evaluation and follow-up of discharge planning. A case manager should be able to coordinate all disciplines that provide services to patients to produce satisfactory and patient-centered care (22)(23). A study conducted by Miculincher, et al (2007) reported that lack of commitment of the head nurse in carrying out his duty as case manager causes $46 \%$ of non conducive services in the ward (24). Another study by Susan, K. Mc Greehan (2005) reported that out of the many number of multidisciplinary models to embrace multidisciplinary, the case manager model is the one which can be implemented (25).

\section{IPPN as Driving Media in the Implementation of Interprofessional Collaborative Practice}

Results of interviews with participants revealed that the IPPN is a medium which can be used as a drivein the implementation of the IPCP. The followings are some statements from the participants.

"It is possible to encourage the implementation of IPCP practices." (P01)

"I think it strongly supports the collaborative practice" (P06)

"By reading the IPPN, there can raise the idea of a joint visite since there are things that should be discussed together for optimal results" (P08) "It can function as communication media between the health professions. The IPPN is the driving force for the implementation of IPCP." (P11)

One of the media which can be used to facilitate the implementation of IPCP is the
IPPN. Documenting IPPN is a non-verbal communication among the health professionals and facilitate them to collaborate (26).

The statements of participants regarding the implementation of IPPN is in line with the theory that medical record documentation functions as a means of communication between health professions in providing services to patients. This communicationis inter-professional communication that aims to prevent the occurrence of misinformation, encourage interdisciplinary coordination, prevent repetitive information, and give assistance in the time management (27).

\section{Workloads, Attitudes, and Behavior of Health Professions and Inappropriate Policy Can Threaten the Existing IPPN Documentation Workloads}

Nine participants mentioned that the workload was an obstacle in documenting the IPPN. Some participants mentioned:

"It is really a difficult time when the polyclinic is full of the patients, as well as the inpatient wards. The work is just so overloaded."(P04)

"We sometimes forget to complete the IPPN due to a lot of work. Sometimes we are about to fill it, but then the patient calls us, or sometimes the doctor is visiting, and some other reasons. It's a very high mobility" (P10)

"Our workload is sometimes overloaded. It is because one pharmacist should be responsible for two wards. Sometimes, the other wards or ICUs also contact us for collaboration with the pharmacists." (P13)

"As much as possible, I complete the IPPN. However, there will always be abusy time. Sometimes there are surgeries or consultation, and thus the record is not maximally fulfilled." (P09) 
"In addition to the IPPN, we should also write the nutritional care. Sometimes, I write the nutritional care in the nutrient installation, and the IPPN is not comprehensively written due to the busy work." (P02).

\section{Attitudes and Behaviors of the Health Personnel}

The negative attitudes and behaviors of health professions that can inhibit the implementation of IPPN, among others are laziness, tiredness, differences in perception, forgetfulness and being in a rush. These are expressed by some patients as below:

"When there is information missing in the IPPN, probably it is because we forget or be in a hurry. There is no intention to do so." (P06)

"Sometimes I feel lazy since I have to fill the IPPN every day. So sometimes I don't do it maximally." (P11)

"The inhibiting factor is the difference of perception. There is only one representative attending the socialization, so there can be adifferent perception. Sometimes we also forget

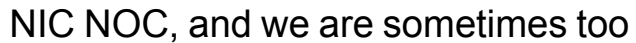
lazy to open the book." (P07)

"Sometimes we are doing it in a hurry, and thus the result is not appropriate with the existing standard." (P11)

\section{Policy (Socialization)}

The results of interviews revealed that the socialization of IPPN conducted by hospital management still lackssince it has not reached all the health professions and has not been thoroughly carried out. The following statements are mentioned by the participants:

"What inhibits the program is because the policy of the hospital which only invites one representativeto be present at the socialization. There is also lack of training to improve the skills of the health professions." (P04)
"IPPN is vigorously socialized before the accreditation; but when the accreditation is over, things go like usual." (P05)

"There is a lack of socialization through workshop/seminar/training. If there is socialization, unfortunately, only one representative, who is usually the head of theunit, is participating. After that, he/she will share the information with others, and this can lead to different perceptions." (P08)

Based on the results of interviews with doctors, nurses, nutritionists, pharmacists, and physiotherapists, it was indicated that the workload, attitudes,and behaviors of health professions and inappropriate policies could be an obstacle if they are not fixed immediately. A study by I Gusti AA showed that there was a relationship between knowledge, attitudes and workloadsand the completeness of documenting process (28). The health professions at UGM hospital, although they have high workload due to a large number of patients and have to share their focus to serve doctor's visit in the inpatients and outpatients, had applied professional attitudes, i.e., prioritizing patient safety, working according to their competence, and being responsible. The health professions have played their roles regarding time allocation, roles of health professions, staff relations, adivision of authority, and joint decision making though they are not yet maximal. Un-optimal attitudes and behaviors in the documentation of IPPN were due to the workload and lack of human resources in the professions of pharmacists, nutritionists, and physiotherapists. As a result, they do not pay attention to the completeness of the document filling.

The policies which inhibited the implementation of IPPN include the limitation of representatives who participated in the program socialization and lack of training related to the documentation of IPPN, as well as the 
lack of SPO socialization. Every good quality management system is always based on SPO which is disseminated to all the competent parties who are to implement it. It is important for every health professionto understandand implementall patient services in accordance with the SPO, including the documentation of IPPN. SPO is a series of written and standardized work instructions on the process of organizing corporate administration, how and when to do and by whom it is implemented (28).

\section{CONCLUSIONS AND SUGGESTIONS Conclusions}

Results of the study indicated that the health professionshad performed the documentation of IPPN with a good understanding and worked in accordance with the role of each profession. Documenting IPPN should reflect collaborative practices so that in the real practice, there will be communication, discussion, cooperation, and coordination in the joint decision making. Documenting IPPN can be a medium or tool in collaborative practice among the health professionals to better optimize the implementation of IPCP. The documentation of IPPN will be optimally implemented if they are equipped with adequate infrastructure, proper motivation, and transparent, continuous and sustainable monitoring and evaluation and feedback system, as well as the role of case manager that can facilitate and become acollaborator for all health professions. The implementation of IPPN by the health professions experienced several obstacles such as workload, attitudes,andbehaviors of the health profession that lead to negative behaviors. Furthermore, the policy related to the socialization of IPPN in the hospitalis not implemented optimally.

\section{Suggestion}

1. The support from hospital management is badly needed. It is in the form of regular mentoring and evaluation activitiesand providing facilities and infrastructures to support the successful documentation of IPPN.

2. The hospital management is expected to provide routine training/workshops/ seminars related to the documentation of IPPN to increase the knowledge and skill of the health personnel.

3. The availability of reward and punishment system can increase the motivation of health personnel in performing the documentation of IPPN in accordance with the standards set by the hospital.

\section{ACKNOWLEDGMENTS}

The researchers would like to thank Prof. dr. Edi Dharmana, M.Sc, Ph.D., Sp. Par (K) and Madya Sulisno, S.Kp., M. Kes as the supervisors who have provided guidance and inputs. The researchers also thanked the participants for their participation in this study.

\section{REFERENCES}

1. Dimitriadou A. Interprofessional Collaboration and Collaboration among Nursing Staff Members in Northern Greece. Int J Caring. 2008;1(3):140-146.

2. Leticia San Martin-Rodriguez MarieDominique Beaulieu Danielle D'Amor Marcela Ferrada-Videla. The determinants of successful collaboration: A review of theoretical and empirical studies. J Interprof Care. 2005;1(May):132-147.

3. Keith, K.M. \& Skin DF. Effective collaboration : The Key to Better Healthcare. Can J Nurs Leadership (CJNL). 2008; 21 (2): 51- 61.

4. Dougherty MB, Larson $E$. A Review of Instruments Measuring Nurse-Physician Collaboration. JONA J Nurs Adm. 2005;35(5):244-253.

5. World Health Organization. World Health Statistics. 2010. 
6. Bleich S. Medical errors: Five Years After The IOM Report. Issue Brief (Commonw Fund). 2005;(830):1-15.

7. Huron Perth Healthcare Alliance. HPHA Interprofessional Practice Model. 2011.

8. Fewster-Thuente $L$ and Velsor-Friedrich $B$. Interdisciplinary Collaboration for Healthcare Professionals, Nurs. Admin. Q. 2008; 32(1): 40-48.

9. Alligood, Martha Raile. Theoretical Nursing : Development\&Progress. 5th edition. 2012.

10. Hariyati TS. Perencanaan Pengembangan Dan Utilisasi Tenaga Keperawatan. Jakarta: Rajawali Pers. 2014.

11. Pratama, Febrina Mega; Sugiyanto Z. KARS Accreditation Readiness Review Section Of Communication And. 2010.

12. JCl. Journal on Quality and Patient Safety, Root Causes of Sentinel Events. 2006.

13. Iyer Patricia W \& NHC. Dokumentasi Keperawatan. Jakarta : EGC; 2005.

14. Basrowi \& Suwandi. Memahami Penelitian Kualitatif. Jakarta: Rineka Cipta; 2008.

15. Sugiyono. Memahami Penelitian Kualitatif. Jakarta: Alfabeta; 2010.

16. JCI Accreditation Standards for Hospitals. 4th Edition. Effective 1 January 2011.

17. Frelita G, Situmorang TJ, \& Silitonga DS. Joint Commission International Accreditation Standards for Hospitals 4 th ed., Oakbrook Terrace, Illinois 60181 U.S.A, 2011.

18. Patricia Suti Lasmani dkk. Evaluation of Integrated Medical Record Implementation Case Study in. 2014;17(1):3-8.

19. Renta, Pagela Pascarella. Evaluasi Pelaksanaan Patient Centered Care di RS PKU Muhammadiyah Yogyakarta Unit 1. 2016.
20. Henki Idris Issakh \& Zahrida Wiryawan. Pengantar Manajemen. Edisi 2. In Media. Jakarta. 2015.

21. Pourasghar, F., Kazemi, A., Malekafzali, h, Ellenius, J., and Fors, U., (2008), What they fill in today, may not be useful tomorrow : Lesson Learned from Studying Medical records at the Woman Hospital in Tabriz, Iran, BMC public health, vol. 8

22. Komisi Akreditasi Rumah Sakit. Panduan Penyusunan Dokumen Akreditasi. 2012.

23. Komisi Akreditasi Rumah Sakit. Panduan Pelaksanaan Dokter Penanggung Jawab Pelayanan (DPJP) dan Case Manajer. 2015

24. Mikulincer, M. , \& Shaver, P. R. Attachment in Adulthood: Structure,Dynamics, AND Changer. New York : Guilford Publication. 2007.

25. Susan K. McGeehan. Case Management in Integrated Models Of Care.Manuscript submitted for publication. 2005.

26. Klehr J, Hafner J, Spelz LM, Steen S, Weaver K. Implementation of standardized nomenclature in the electronic medical record. Int J Nurs Terminol Classif. 2009;20(4):169-180. doi:10.1111/j.1744618X.2009.01132.x.

27. Mastini, I Gusti AA Putri. Hubungan Pengetahuan, Sikap, dan Beban Kerja dengan kelengkapan Pendokumentasian Asuhan Keperawatan IRNA di Rumah Sakit Umum Pusat Sanglah Denpasar. 2013.

28. Atmoko T. Standar Operasional Prosedur (SOP) dan Jurnal Manajemen Pelayanan Kesehatan. 2011; 14(1): Akuntabilitas Kinerja Instansi Pemerintah. [Research]. 36-43. Universitas Diponegoro, Semarang. 2008 